\title{
"A Study on Factors Influencing the Consumer Buying Behaviour With Respect to Nykaa"
}

\author{
Vyshnosri Pendyala, Marketing 2019-21 \\ Sri Balaji University, Pune, India. \\ D.0.I-10.51201/12291 \\ https://doi.org/10.51201/12291
}

\section{RESEARCH ABSTRACT}

A few years ago, industries like beauty and personal care thrived more on the store experience of touch, feel and smell. We never knew that industries like beauty and personal care would probably make their way into digital platforms. We are all well-known with the fact that the evolution of e-commerce sites has made lives easier, simpler and time-saving in the world. Through this the changing trends have proved that the beauty and personal care industries are no exception to the digital mode.

This paper explains about how did the e-commerce platforms have changed the way consumers choose online medium of shopping over the offline and the factors effecting the buying behaviour of the consumers regarding an online platform, Nykaa, with respect to their purchase of cosmetic and beauty products.

\section{INTRODUCTION}

Nykaa, an Indian e-commerce company located its headquarters at Mumbai, Maharashtra, is the largest beauty shopping destination in India. It reaches over 1000 cities across India and it has 650+ brands in which 25 are high end brands such as MAC, Clinique, Estee lauder, NYX, Bobbi Brown, etc. Nykaa also has 33 physical outlets which are categorized into Nykaa on trend and Nykaa luxe.

Nykaa has reached out to the market in a very smart way. It has used the Porter's value chain framework as a tool which is used to add up competitive advantage through price fluctuations in the market. The main focus of this analysis is the differences in the business activities and relative pricing and costing concept of Nykaa. It operates at a lower cost and commands a good premium.

This analysis is divided into 2 types

- Primary value chain

- Supporting value chain

\section{PRIMARY VALUE CHAIN}

The primary value chain usually works on 5 categories i.e.,

- Inbound logistics- which deals with the warehousing and material handling.

- Operations- which deals with the raw materials being turned into finished goods, also the consumer data is collected from the database to build the companies strategies based on the consumer buying behaviour.

- Outbound logistics- this deals with the distribution of the final products to the end consumers. 
- Marketing \& sales- this is the main activity that focuses on creating a sales medium where Nykaa's potential customers can buy its products. Activities such as selecting channels, pricing strategies, ad campaigns and promotional activities etc. are also included in this category.

- Services- this deals with the post sales activities such as tracking the post-sale data information and maintaining it for further progress of the company.

\section{SUPPORTING VALUE CHAIN}

The supporting value chain is used to support the primary value chain of the company and these are further classified into 4 activities, they are:

- Firm infrastructure- It deals with the general management, quality management, finance \& accounting, planning \& legal services of the company.

- HRM- It deals with the activities like recruitment, selection \& hiring employees, training \& development etc. This is the activity that supports the company and does not have any negative effect on the competitive advantage of the company.

- Tech-development- It deals with the activities such as field testing, tech-selection, component \& feature design and process engineering.

- Procurement activities- The procurement activities are used to make input purchases like raw materials, lab equipment, machinery needs etc. to the company. This is also used to evaluate the company's on-going performance.

Nykaa follows the inventory based e-commerce model where the goods are purchased directly from the manufacturer and these goods are stored in Nykaa's warehouses. Now these goods are sold directly from the warehouse, and due to this the profit margin is high.

Nykaa's biggest competitor is the brand SEPHORA, which sells only high end products. Whereas Nykaa sells all types of products ranging from high end to low end. If observed carefully there is no such renowned brand that Nykaa doesn't sell.Nykaa did not just stick to one set of audience, but has targeted all sets of audience ranging from lower economic standard to higher economic standard. This is how the brand Nykaa has gained popularity in the country. Nykaa purchases the products directly from the brands which helps it getting high commission over the products. Nykaa does not give discounts themselves on any brand but the brands themselves give the discount so that it does not reduce their commission. And that is the reason why Nykaa is cheaper and saves the time of a customer from going to market. So if any customer gets any discount or any gift voucher or a free article, it's from the original brand but not Nykaa. After 5 years of ups and downs, Nykaa has got its break-even point and later on the company was in profits. Apart from selling the other brands, Nykaa has started its own product line focussing on all types of customers and explaining them that the products that they're searching for are also available in their own brand name. Now that 50\% of the crowd that Nykaa gets are the repeat customers showing that their retention game is strong and they work hard on the other $50 \%$ of the crowd. This is how Nykaa has become the largest beauty shopping destination in India. According to a recent article published in the economic times, Nykaa has 33\% share of the online beauty market in FY 2018.

\section{RESEARCH PROBLEM}

Nykaa being one of the leading shopping platforms in beauty and cosmetic industry, none of the researchers have studied in detail about the company and did not explore about what could be the factors that influence consumer buying behaviour towards Nykaa as a platform for the purchase of beauty products. So the question is what are the factors influencing the consumer buying behaviour of Nykaa? 


\section{LITERATURE REVIEW}

KEYWORDS: Consumer buying behaviour, online buying behaviour, factors influencing the buying behaviour.

Dr S.A. Mohamed Ali and Ramya N in their research study have mentioned that "Consumer Buying Behaviour refers to selection, purchase and consumption of goods and services for the satisfaction of their wants." Consumer buying behaviour involves different processes. There are many factors that influence an individual in ever purchase decision that he/she makes. And as said by the authors, a purchase decision is the result of each and every factor that influences a consumer.

\section{FACTORS INFLUENCING CONSUMER BUYING BEHAVIOUR}

Several factors that influence the consumer buying behaviour are:

1) Internal or psychological factors

2) Social factors

3) Cultural factors

4) Economic factors

5) Personal factors

The above are the factors which measure the consumer's motivation, perceptions, beliefs, attitude, role, status, culture, sub-culture, social class, income, lifestyle, occupation and personality etc. The five questions that support any understanding of consumer buying behaviour are who, what, why, how, when and where do they buy.

As mentioned in a study by A.K. Rastogi,2010, "consumers decide whether, what, when, from whom to buy. They can avail various mediums to buy the products." As this paper is about the e-commerce platform, we are going to discuss about the online shopping behaviour. The attitude towards online shopping is not only affected by ease of use, usefulness and enjoyment, but also there are factors such as consumer individuality, situational factors, product distinctiveness, previous shopping experience and most importantly the faith in online shopping.

Prasad A and Gudimetla S, 2019, in their study of digital shopping behaviour of women with respect to beauty and personal care products, have said that "online shopping behaviour is a crucial part of e-commerce which is often given less importance when compared to the other factors like technology, digital marketing etc." Online shopping behaviour explains us about a consumer's overall perception and evaluation for product during they are buying the product which could result in bad or good way. There are several variables to measure the behaviour, they are, the preferred time of purchase, intention of the buyer, demographic and cultural backgrounds of a consumer and also these could be the factors that influence a consumer.

In a study, the authors, Bhatt $\mathrm{S}$ and Bhatt A,2012, mentioned that factors such as time, availability of products, affordable price, promotions that e-retailers provide and ease in payment methods encourage the young minds to shop more online. We all know that internet is most used by the people who lie between age group of 20-35 years. So most of the e-retailers keep this particular age group in mind before they promote any brand.

Also it was mentioned in another study by Anjana SS, 2018, that before buying a product, consumers follow a series of steps. They evaluate the product in such a way that the features of the product meet the consumer's needs and expectations. These needs consist of good quality with low or affordable price and 
should deliver the consumer with value added features. When it comes to the product quality, price, features, packaging etc. the consumer buying pattern differs. Consumers follow the fashion and changing trends that affect their buying pattern.

\section{RESEARCH METHODOLOGY}

\section{OBJECTIVES:}

1) To study and analyse the online consumer buying behaviour.

2) To assess the behavioural level of customers of different age group.

3) To understand the factors influencing the consumer buying behaviour with respect to Nykaa.

\section{HYPOTHESIS FORMULATION:}

1) H0: Age has no significant effect on consumer buying behaviour.

Ha: Age has significant effect on consumer buying behaviour.

2) H0: Price has no significant impact on consumer buying behaviour.

Ha: Price has significant impact on consumer buying behaviour.

3) H0: Quality has no significant impact on consumer buying behaviour. Ha: Quality has significant impact on consumer buying behaviour.

4) H0: Availability of brands have no significant impact on consumer buying behaviour.

Ha: Availability of brands have significant impact on consumer buying behaviour.

5) H0: Social media/social media influencers have no significant impact on consumer buying behaviour.

Ha: Social media/social media influencers have significant impact on consumer buying behaviour.

6) H0: Brand name has no significant impact on consumer buying behaviour.

Ha: Brand name has a significant impact on consumer buying behaviour.

\section{RESEARCH DESIGN:}

The research design applied was descriptive design. This design helps to describe a population, situation or a phenomenon. This was mainly used to answer the questions like what, when, where, when and how.

\section{RESEARCH METHOD:}

Quantitative approach is the method used in the research. This method helps to analyse the data statistically or we can say that numerical analysis is done through questionnaires and surveys. Quantitative method focuses more on gathering numerical data and generalising it across groups of respondents or to explain a particular phenomenon

\section{PRIMARY DATA:}

Primary data was collected through an online questionnaire to a set of respondents who are believed to have desired information.

\section{SECONDARY DATA:}

Various published articles regarding consumer buying behaviour and about the company Nykaa were referred for the secondary data collection. 


\section{SAMPLING DESIGN:}

Convenient sampling was adopted in selecting the respondents to collect the data. Data has been collected from a sample of 146 respondents.

\section{STATISTICAL ANALYSIS OF DATA:}

The collected data were carefully analysed and evaluated. Statistical tools such as chi-square test and multilinear regression analysis were applied to interpret the data to draw meaningful results.

\section{DATA ANALYSIS}

\section{1) Gender classification of the respondents.}

\section{FIGURE 1}

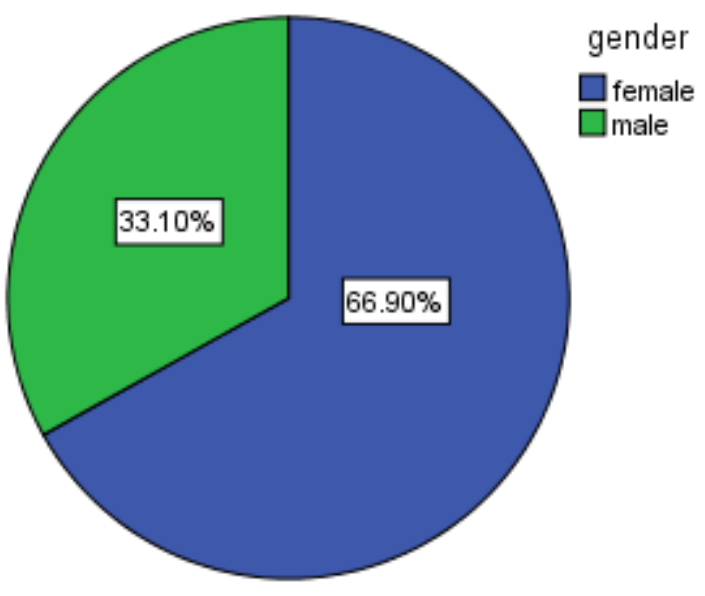

Gender (table 1.1)

\begin{tabular}{|c|c|c|c|c|c|}
\hline & & Frequency & Percent & Valid Percent & $\begin{array}{c}\text { Cumulative } \\
\text { Percent }\end{array}$ \\
\hline \multirow[t]{3}{*}{ Valid } & female & 97 & 66.9 & 66.9 & 66.9 \\
\hline & male & 48 & 33.1 & 33.1 & 100.0 \\
\hline & Total & 145 & 100.0 & 100.0 & \\
\hline
\end{tabular}

Interpretation: It is seen from the above pie chart and the table 1.1, that the males constitute $33.10 \%$ and females constitute $66.90 \%$. Here it is evident that female play the major role. 


\section{2) Age wise classification of the respondents.}

\section{FIGURE 2}

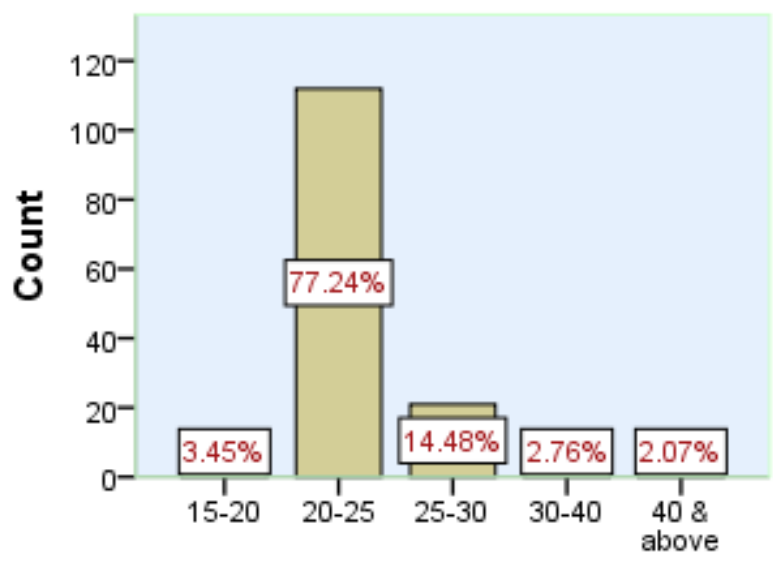

age

Age (table 1.2)

\begin{tabular}{|ll|r|r|r|r|}
\hline & Frequency & Percent & Valid Percent & $\begin{array}{c}\text { Cumulative } \\
\text { Percent }\end{array}$ \\
\hline Valid & $15-20$ & 5 & 3.4 & 3.4 & 3.4 \\
& $20-25$ & 112 & 77.2 & 77.2 & 80.7 \\
$25-30$ & 21 & 14.5 & 14.5 & 95.2 \\
$30-40$ & 4 & 2.8 & 2.8 & 97.9 \\
40 \& above & 3 & 2.1 & 2.1 & 100.0 \\
Total & 145 & 100.0 & 100.0 & \\
\hline
\end{tabular}

Interpretation: From the above table 1.2, we can see that $77.2 \%$ of the respondents fall under the age group of $20-25,14.5 \%$ of the respondents fall under the age group of $25-30,3.4 \%$ of the respondents fall under the age group of $15-20,2.8 \% \& 2.1 \%$ under $30-40$ and $40 \&$ above respectively. 
3) Classification of the respondents based on their purchase of beauty products.

\section{FIGURE 3}

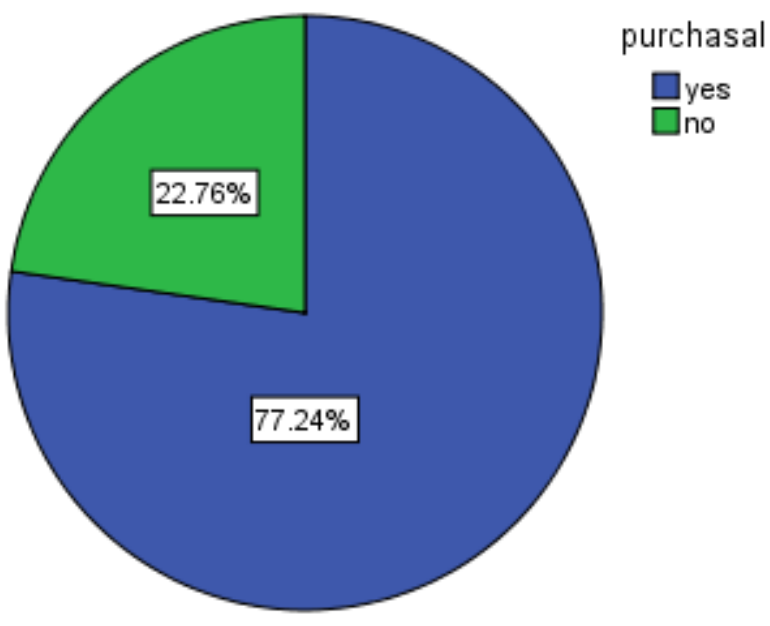

Purchase (table 1.3)

\begin{tabular}{|c|c|c|c|c|c|}
\hline & & Frequency & Percent & Valid Percent & $\begin{array}{c}\text { Cumulative } \\
\text { Percent }\end{array}$ \\
\hline \multirow[t]{3}{*}{ Valid } & yes & 112 & 77.2 & 77.2 & 77.2 \\
\hline & no & 33 & 22.8 & 22.8 & 100.0 \\
\hline & Total & 145 & 100.0 & 100.0 & \\
\hline
\end{tabular}

Interpretation: From the above table 1.3 , we can see that $77.2 \%$ of the respondents have said that they buy beauty products online and $22.7 \%$ have said that they do not purchase cosmetic products online.

4) Classification of the online platform selection of the $77.2 \%$ respondents. Figure 4

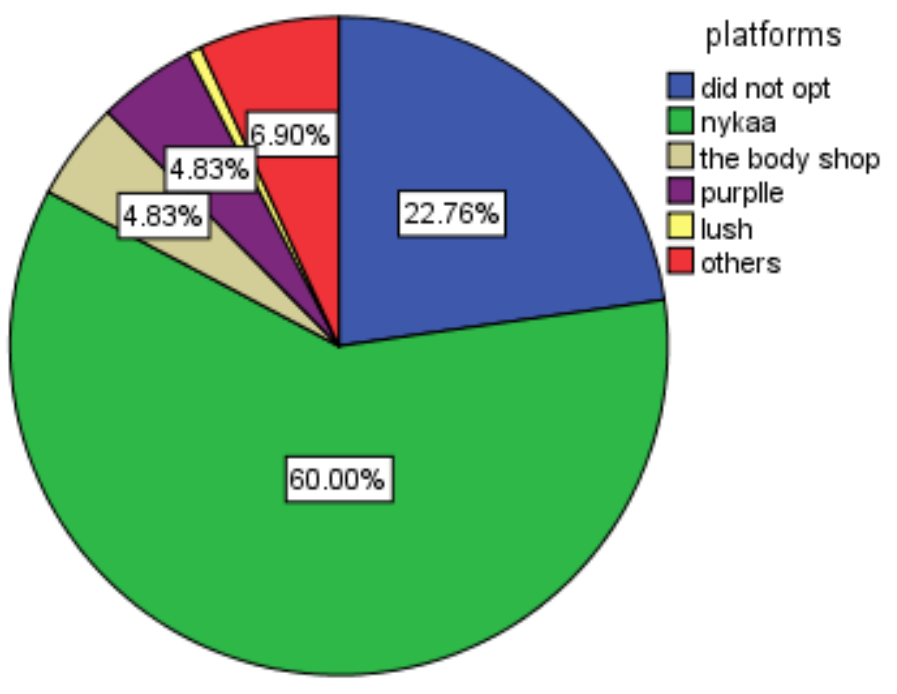




\section{Platforms (table 1.4)}

\begin{tabular}{|l|r|r|r|r|}
\hline & Frequency & Percent & Valid Percent & $\begin{array}{c}\text { Cumulative } \\
\text { Percent }\end{array}$ \\
\hline Valid did not opt & 33 & 22.8 & 22.8 & 22.8 \\
& 87 & 60.0 & 60.0 & 82.8 \\
nykaa & 7 & 4.8 & 4.8 & 87.6 \\
the body shop & 7 & 4.8 & 4.8 & 92.4 \\
purplle & 1 & .7 & .7 & 93.1 \\
lush & 10 & 6.9 & 6.9 & 100.0 \\
others & 145 & 100.0 & 100.0 & \\
Total & &
\end{tabular}

Interpretation: From the table 1.4 , it is clearly seen that $60 \%$ of the respondents from $77.2 \%$ chooseNykaa as their online shopping platform for buying beauty products which is a huge number. And the rest are the $17.2 \%$ respondents who choose other platforms over Nykaa.

\section{5) Classification of type of customer of the $60 \%$ of respondents who chose Nykaa as their platform.}

\section{FIGURE 5}

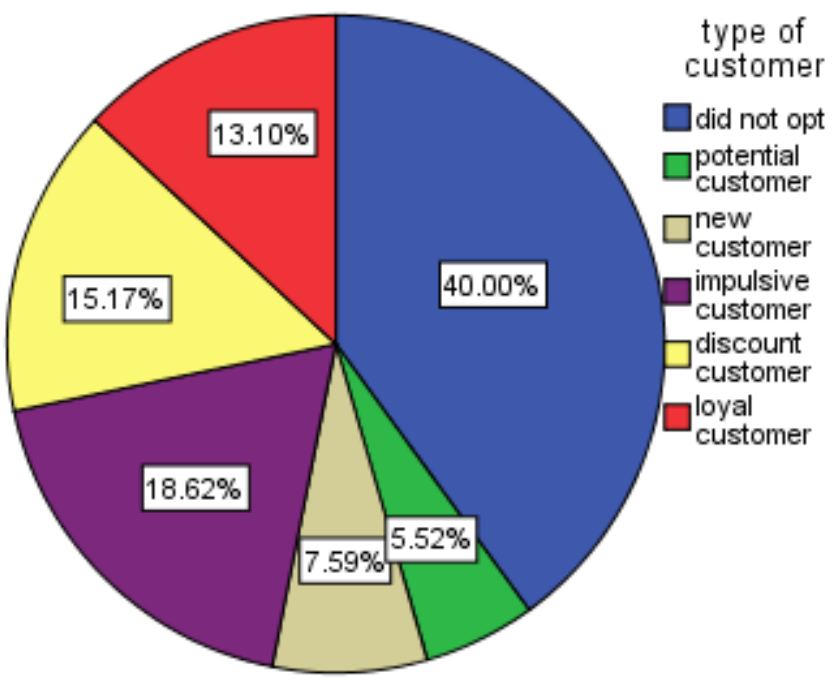


Type of customer (table 1.5)

\begin{tabular}{|l|r|r|r|r|}
\hline & Frequency & Percent & Valid Percent & $\begin{array}{c}\text { Cumulative } \\
\text { Percent }\end{array}$ \\
\hline Valid did not opt & 58 & 40.0 & 40.0 & 40.0 \\
potential customer & 8 & 5.5 & 5.5 & 45.5 \\
new customer & 11 & 7.6 & 7.6 & 53.1 \\
impulsive customer & 27 & 18.6 & 18.6 & 71.7 \\
discount customer & 22 & 15.2 & 15.2 & 86.9 \\
loyal customer & 19 & 13.1 & 13.1 & 100.0 \\
Total & 145 & 100.0 & 100.0 & \\
\hline
\end{tabular}

Interpretation: From the above table 1.5, we can see that $18.62 \%$ respondents are impulsive customers, $15.17 \%$ are discount customers, $13.10 \%$ are the loyal customers, $7.59 \%$ are the new customers and $5.52 \%$ are the potential customers. These sum up to that $60 \%$ of the customers who chose Nykaa as their platform. $22.76 \%$ of respondents who do not purchase beauty products online and the rest are the $17.24 \%$ who purchase beauty products online but do not choose Nykaa as their platform to purchase. These two sum up to the $40 \%$ of the respondents who fall under the option "did not opt" as shown in the table.

\section{6) Classification of the $60 \%$ of respondents who choose Nykaa based on their reliability on the brand.}

\section{FIGURE 6}

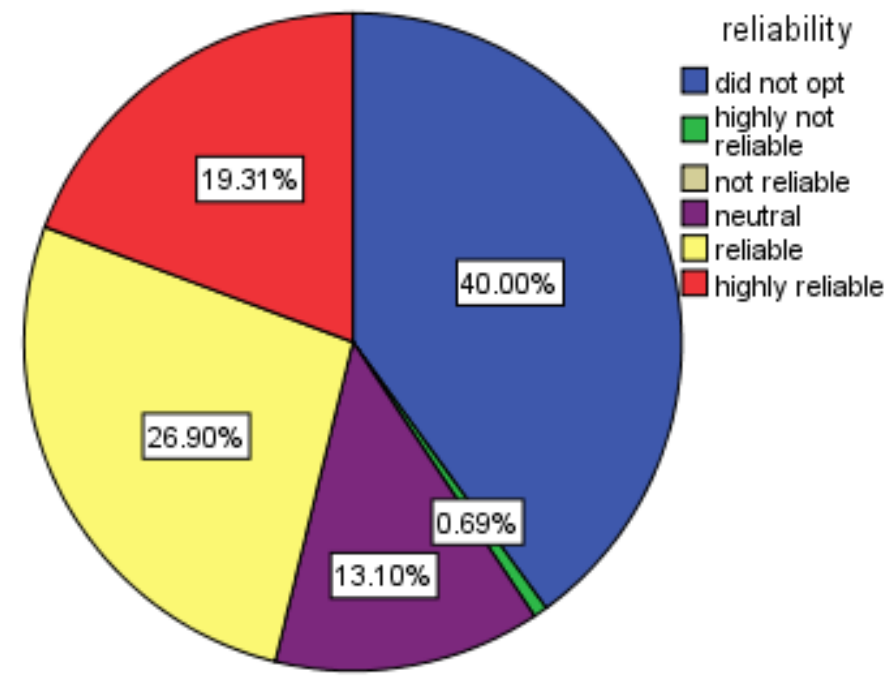




\section{Reliability (table 1.6)}

\begin{tabular}{|l|r|r|r|r|}
\hline & Frequency & Percent & Valid Percent & $\begin{array}{c}\text { Cumulative } \\
\text { Percent }\end{array}$ \\
\hline Valid did not opt & 58 & 40.0 & 40.0 & 40.0 \\
highly not & 1 & .7 & .7 & 40.7 \\
reliable & & & & \\
neutral & 19 & 13.1 & 13.1 & 53.8 \\
reliable & 39 & 26.9 & 26.9 & 80.7 \\
highly reliable & 28 & 19.3 & 19.3 & 100.0 \\
Total & 145 & 100.0 & 100.0 & \\
\hline
\end{tabular}

Interpretation: As we can see from the above table 1.6, $19.31 \%$ of the respondents are highly reliable and $26.90 \%$ of them are reliable from the total of $60 \%$ of the respondents who choose Nykaa. $13.10 \%$ of the respondents are neutral about the reliability.

\section{7) Classification based on satisfaction levels about the brand.}

\section{FIGURE 7}

8)

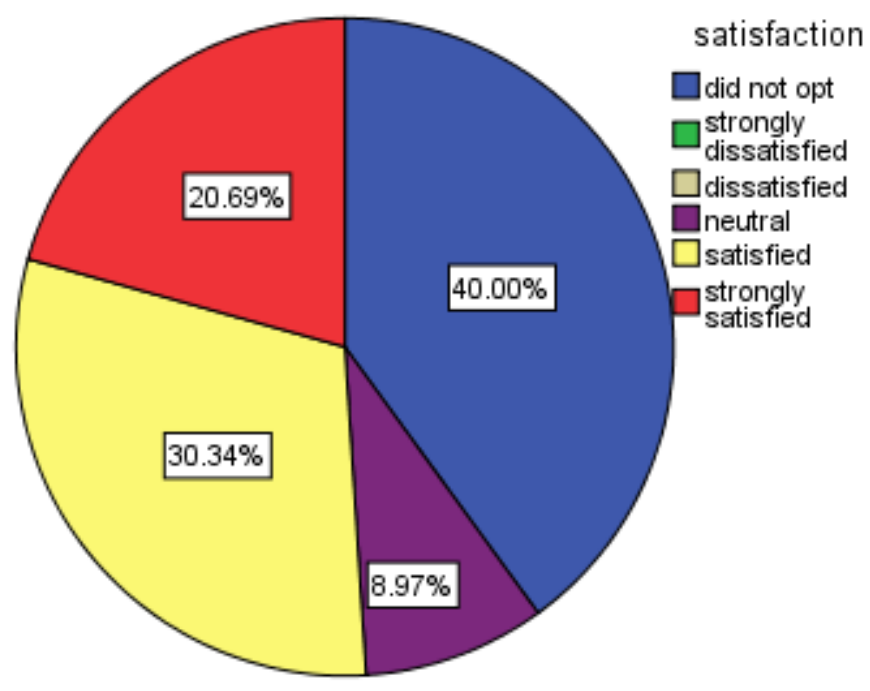


Satisfaction (table 1.7)

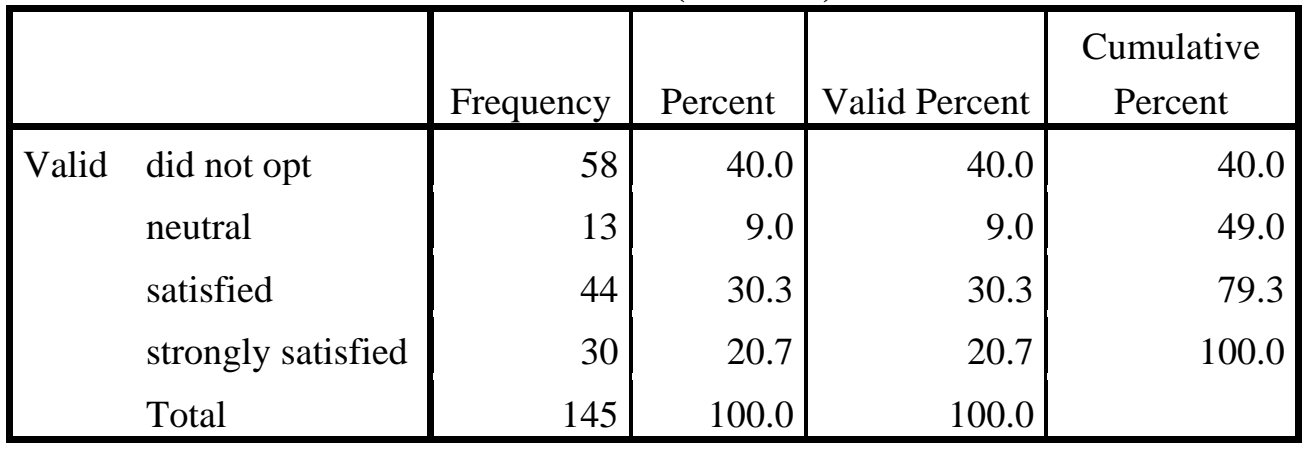

Interpretation: From the above table 1.7, we can see that $20.7 \%$ are strongly satisfied with the brand, $30.3 \%$ are satisfied and $9.0 \%$ are neutral about the satisfactory level.

9) Classification of the $60 \%$ of respondents who chose Nykaa based on choosing any other brand which is similar to Nykaa.

FiguRE 8

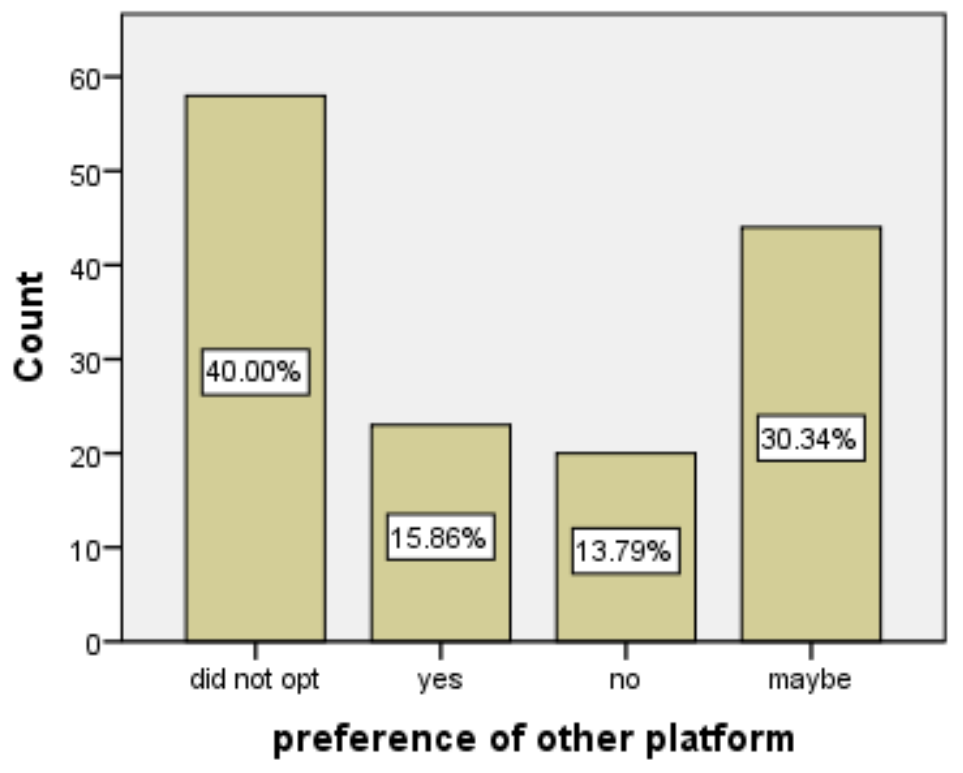


Preference of other platform (table 1.8)

\begin{tabular}{|l|r|r|r|r|}
\hline & Frequency & Percent & Valid Percent & $\begin{array}{c}\text { Cumulative } \\
\text { Percent }\end{array}$ \\
\hline Valid did not opt & 58 & 40.0 & 40.0 & 40.0 \\
& 23 & 15.9 & 15.9 & 55.9 \\
yes & 20 & 13.8 & 13.8 & 69.7 \\
no & 44 & 30.3 & 30.3 & 100.0 \\
maybe & 145 & 100.0 & 100.0 & \\
Total & &
\end{tabular}

Interpretation: As we can see from the above table 1.8, that $13.8 \%$ of the respondents from the $60 \%$ of the respondents who chose Nykaa have responded "no" when asked if they would choose any other platform similar to Nykaa. $30.3 \%$ have responded "maybe" which means they do not have a clarity about it. 15.9\% have responded that they would choose.

10) Classification of the $22.76 \%$ of the respondents who do not purchase beauty products based on their reasons for not purchasing.

\section{FIGURE 9}

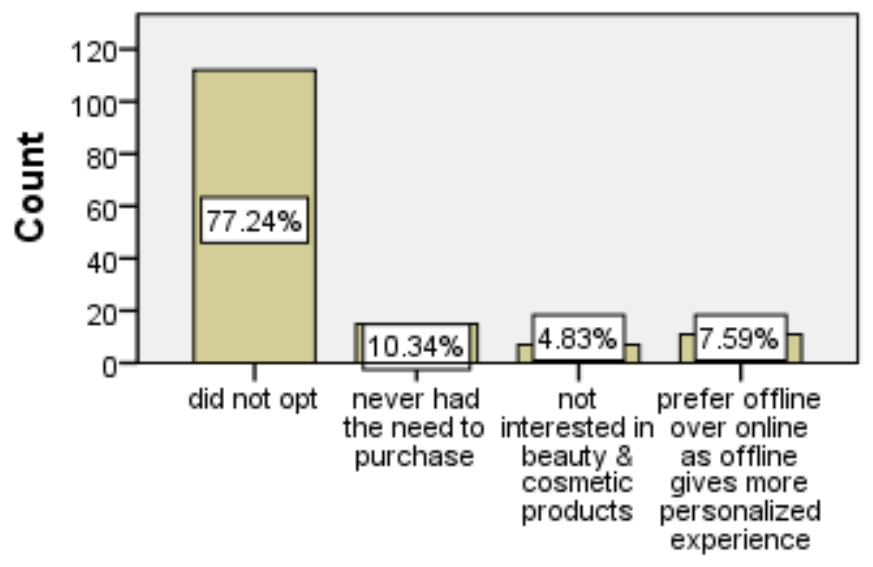

reason for not purchasing 
Reason for not purchasing (table 1.9)

\begin{tabular}{|l|r|r|r|r|}
\hline & Frequency & Percent & \multicolumn{1}{|c|}{$\begin{array}{c}\text { Valid } \\
\text { Percent }\end{array}$} & $\begin{array}{c}\text { Cumulative } \\
\text { Percent }\end{array}$ \\
\hline Valid did not opt & 112 & 77.2 & 77.2 & 77.2 \\
never had the need to & 15 & 10.3 & 10.3 & 87.6 \\
purchase & & & & \\
not interested in beauty & 7 & 4.8 & 4.8 & 92.4 \\
$\begin{array}{l}\text { \& cosmetic products } \\
\text { prefer offline over }\end{array}$ & 11 & 7.6 & 7.6 & 100.0 \\
online as offline gives & & & & \\
more personalized & & & & \\
experience & & & & \\
Total & 145 & 100.0 & 100.0 & \\
\hline
\end{tabular}

Interpretation: As we can see from the table 1.9, amongst the $22.76 \%$ of the respondents who do not purchase beauty products online, $10.3 \%$ of the respondents said that they never got the need to buy. $4.8 \%$ of the respondents said that they are not interested in beauty products and $7.6 \%$ of the respondents said that they prefer offline shopping over online as offline gives more personalized experience.

11) Classification of the $22.76 \%$ of the respondents who do not purchase beauty products online based on an imaginary question asked about what platform they would choose if they had to purchase beauty products online.

\section{FIGURE 10}

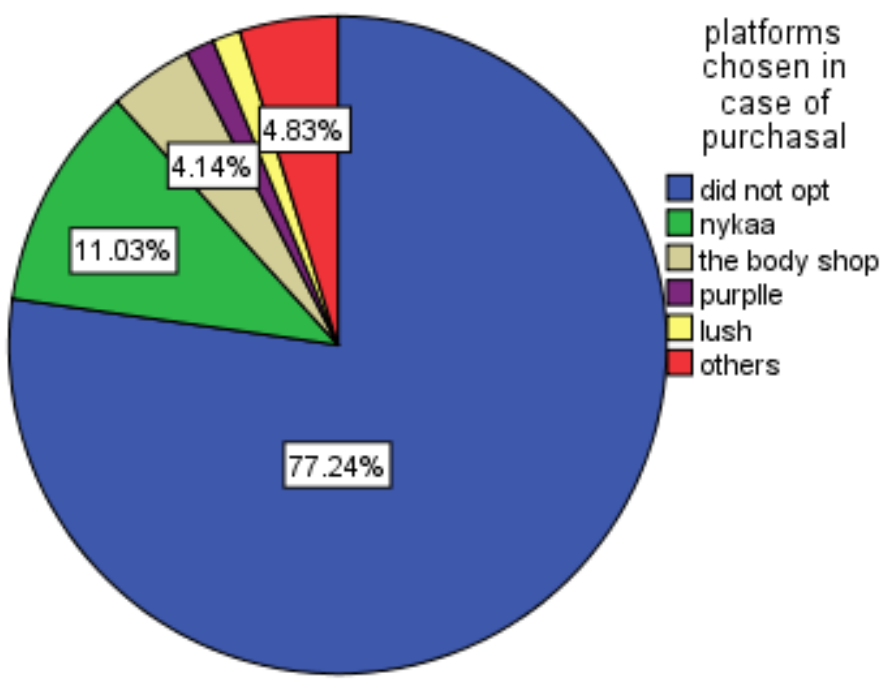


Platforms chosen in case of purchase (table 2.0)

\begin{tabular}{|l|r|r|r|r|}
\hline & Frequency & Percent & Valid Percent & $\begin{array}{c}\text { Cumulative } \\
\text { Percent }\end{array}$ \\
\hline Valid did not opt & 112 & 77.2 & 77.2 & 77.2 \\
nykaa & 16 & 11.0 & 11.0 & 88.3 \\
the body shop & 6 & 4.1 & 4.1 & 92.4 \\
purplle & 2 & 1.4 & 1.4 & 93.8 \\
lush & 2 & 1.4 & 1.4 & 95.2 \\
others & 7 & 4.8 & 4.8 & 100.0 \\
Total & 145 & 100.0 & 100.0 & \\
\hline
\end{tabular}

Interpretation: From the above table 2.0, we can see that $11.03 \%$ of the respondents out of $22.76 \%$ prefer Nykaa as their platform in case they have to purchase beauty products online.

\section{HYPOTHESIS TESTING}

\section{1) Reliability test (Cronbach's alpha):}

Reliability Statistics (table 2.1)

\begin{tabular}{|c|c|c|}
\hline $\begin{array}{c}\text { Cronbach's } \\
\text { Alpha }\end{array}$ & $\begin{array}{c}\text { Cronbach's } \\
\text { Alpha Based } \\
\text { on } \\
\text { Standardized } \\
\text { Items }\end{array}$ & $\mathrm{N}$ of Items \\
\hline .885 & .867 & 22 \\
\hline
\end{tabular}

Interpretation: From the above table 2.1, we can see that the significant value is 0.885 which is greater than 0.7 , this signifies that the data is reliable.

\section{2) Cross tabs:}

\section{Hypothesis:1}

Null H0: Age has no significant impact on consumer buying behaviour.

Alternative Ha: Age has significant impact on consumer buying behaviour. 
age * agreeness level Cross tabulation

\begin{tabular}{|c|c|c|c|c|c|c|}
\hline \multicolumn{7}{|c|}{ Count } \\
\hline & & \multicolumn{4}{|c|}{ agreeness level } & \multirow[b]{2}{*}{ Total } \\
\hline & & did not opt & strongly agree & agree & neutral & \\
\hline \multirow[t]{5}{*}{ age } & $15-20$ & 3 & 0 & 1 & 1 & 5 \\
\hline & $20-25$ & 43 & 39 & 24 & 6 & 112 \\
\hline & $25-30$ & 8 & 10 & 3 & 0 & 21 \\
\hline & $30-40$ & 2 & 1 & 1 & 0 & 4 \\
\hline & $40 \&$ above & 2 & 1 & 0 & 0 & 3 \\
\hline Total & & 58 & 51 & 29 & 7 & 145 \\
\hline
\end{tabular}

Chi-Square Tests (table 2.2)

\begin{tabular}{|l|r|r|r|}
\hline & \multicolumn{1}{|c|}{ Value } & \multicolumn{1}{c|}{ df } & \multicolumn{1}{c|}{$\begin{array}{c}\text { Asymp. Sig. } \\
\text { (2-sided) }\end{array}$} \\
\hline Pearson Chi-Square & $8.941^{\mathrm{a}}$ & 12 & .708 \\
Likelihood Ratio & 11.379 & 12 & .497 \\
Linear-by-Linear & 1.897 & 1 & .168 \\
Association & & & \\
N of Valid Cases & 145 & & \\
\hline
\end{tabular}

a. 14 cells $(70.0 \%)$ have expected count less than 5 . The minimum expected count is .14.

Interpretation: From the above table 2.2, we can see that the significant value of the chi-square is 0.708 i.e. the value is greater than 0.05 . So we accept the null hypothesis, that age has no significant effect on consumer buying behaviour and we reject the alternate hypothesis, that the age has significant effect on consumer buying behaviour.

\section{3) Multi linear regression analysis:}

\section{Hypothesis: 2,3,4,5 \& 6}

Null H0: Price has no significant impact on consumer buying behaviour.

Alternative Ha: Price has significant impact on consumer buying behaviour.

Null H0: Quality has no significant impact on consumer buying behaviour.

Alternative Ha: Quality has significant impact on consumer buying behaviour.

Null H0: Availability of brands have no significant impact on consumer buying behaviour.

Alternative Ha: Availability of brands have significant impact on consumer buying behaviour. 
Null H0: Social media/social media influencers have no significant impact on consumer buying behaviour.

Alternative Ha: Social media/social media influencers have significant impact on consumer buying behaviour.

Null H0: Brand name has no significant impact on consumer buying behaviour.

Alternative Ha: Brand name has a significant impact on consumer buying behaviour.

Table 2.3

\begin{tabular}{|c|c|c|c|c|c|c|c|c|}
\hline \multirow{2}{*}{\multicolumn{2}{|c|}{ Model }} & \multirow[b]{2}{*}{$\begin{array}{c}\text { Beta } \\
\text { In } \\
\end{array}$} & \multirow[b]{2}{*}{$\mathrm{t}$} & \multirow[b]{2}{*}{ Sig. } & \multirow[b]{2}{*}{$\begin{array}{c}\text { Partial } \\
\text { Correlation } \\
\end{array}$} & \multicolumn{3}{|c|}{ Collinearity Statistics } \\
\hline & & & & & & $\begin{array}{c}\text { Tolera } \\
\text { nce }\end{array}$ & VIF & $\begin{array}{l}\text { Minimum } \\
\text { Tolerance }\end{array}$ \\
\hline \multirow[t]{9}{*}{1} & $\begin{array}{l}\text { availability of } \\
\text { variety of brands }\end{array}$ & $.229^{\mathrm{a}}$ & 2.751 & .007 & .225 & .469 & 2.133 & .469 \\
\hline & price & $.173^{\mathrm{a}}$ & 2.027 & .045 & .168 & .457 & 2.188 & .457 \\
\hline & $\begin{array}{l}\text { personalized } \\
\text { customer service }\end{array}$ & $.167^{\mathrm{a}}$ & 1.485 & .140 & .124 & .267 & 3.749 & .267 \\
\hline & quality & $.112^{a}$ & 1.303 & .195 & .109 & .458 & 2.184 & .458 \\
\hline & packging & $.181^{\mathrm{a}}$ & 1.731 & .086 & .144 & .309 & 3.235 & .309 \\
\hline & discounts/offers & $.153^{\mathrm{a}}$ & 1.653 & .101 & .137 & .390 & 2.562 & .390 \\
\hline & $\begin{array}{l}\text { celebrity } \\
\text { endorsements }\end{array}$ & $.247^{\mathrm{a}}$ & 2.657 & .009 & .218 & .380 & 2.634 & .380 \\
\hline & $\begin{array}{l}\text { socialmedia / } \\
\text { social media } \\
\text { influencers }\end{array}$ & $.296^{\mathrm{a}}$ & 3.531 & .001 & .284 & .450 & 2.222 & .450 \\
\hline & brand name & $.319^{a}$ & 3.276 & .001 & .265 & .337 & 2.966 & .337 \\
\hline \multirow[t]{10}{*}{2} & $\begin{array}{l}\text { availability of } \\
\text { variety of brands }\end{array}$ & $.121^{b}$ & 1.303 & .195 & .109 & .367 & 2.725 & .352 \\
\hline & price & $.104^{b}$ & 1.208 & .229 & .101 & .426 & 2.348 & .343 \\
\hline & personalized & - & -.227 & .821 & -.019 & .202 & 4.943 & .202 \\
\hline & customer service & $.028^{b}$ & & & & & & \\
\hline & quality & - & -.149 & .882 & -.013 & .377 & 2.653 & .370 \\
\hline & & $.014^{b}$ & & & & & & \\
\hline & packging & $.028^{b}$ & .244 & .808 & .021 & .248 & 4.029 & .248 \\
\hline & discounts/offers & $.019^{b}$ & .194 & .846 & .016 & .317 & 3.155 & .317 \\
\hline & $\begin{array}{l}\text { celebrity } \\
\text { endorsements }\end{array}$ & $.061^{b}$ & .500 & .618 & .042 & .215 & 4.659 & .215 \\
\hline & brand name & $.217^{\mathrm{b}}$ & 2.086 & .039 & .173 & .284 & 3.522 & .284 \\
\hline
\end{tabular}




\begin{tabular}{|c|c|c|c|c|c|c|c|c|}
\hline \multirow[t]{8}{*}{3} & $\begin{array}{l}\text { availability of } \\
\text { variety of brands }\end{array}$ & $-.013^{c}$ & -.108 & .914 & -.009 & .203 & 4.934 & .157 \\
\hline & price & $.035^{\mathrm{c}}$ & .376 & .707 & .032 & .350 & 2.853 & .234 \\
\hline & $\begin{array}{l}\text { personalized } \\
\text { customer service }\end{array}$ & $-.112^{c}$ & -.870 & .386 & -.073 & .185 & 5.394 & .185 \\
\hline & quality & $-.180^{c}$ & - & .102 & -.138 & .254 & 3.941 & .191 \\
\hline & & & 1.647 & & & & & \\
\hline & packging & $-.084^{c}$ & -.686 & .494 & -.058 & .205 & 4.883 & .205 \\
\hline & discounts/offers & $-.035^{c}$ & -.339 & .735 & -.029 & .297 & 3.370 & .266 \\
\hline & $\begin{array}{l}\text { celebrity } \\
\text { endorsements }\end{array}$ & $.043^{c}$ & .360 & .720 & .030 & .214 & 4.682 & .214 \\
\hline
\end{tabular}

a. Predictors in the Model: (Constant), delivery system

b. Predictors in the Model: (Constant), delivery system, socialmedia / social media influencers

c. Predictors in the Model: (Constant), delivery system, socialmedia / social media influencers, brand name

d. Dependent Variable: agreeness level

Interpretation: From the above table 2.3, we can see that the significant values of availability of brands, price, social media/social media influencers and brand name are $0.007,0.045,0.001 \& 0.001$ respectively. These values are smaller than 0.05. So we accept the alternate hypothesis for each of the following factors i.e. availability of brands, price, social media/social media influencers and brand name have a significant impact on the consumer buying behaviour. Therefore, we reject the null hypothesis for the same.

Coming to quality, its significant value being greater than 0.05 which is 0.195 , we accept the null hypothesis for the following i.e. quality has no significant effect on consumer buying behaviour and we reject the alternate hypothesis i.e. quality has a significant effect on consumer buying behaviour.

\section{FINDINGS OF THE STUDY}

- From the study, it was found that the males constitute $33.10 \%$ and females constitute $66.90 \%$. Here it is evident that female play the major role.

- $77.2 \%$ of the respondents fall under the age group of $20-25,14.5 \%$ of the respondents fall under the age group of $25-30,3.4 \%$ of the respondents fall under the age group of $15-20,2.8 \% \& 2.1 \%$ under $30-40$ and $40 \&$ above respectively.

- $77.2 \%$ of the respondents have said that they buy beauty products online and $22.7 \%$ have said that they do not purchase cosmetic products online. This statement helps in proving the first objective of the study i.e. to study and analyse the online consumer buying behaviour.

- $60 \%$ of the respondents from $77.2 \%$ choose Nykaa as their online shopping platform for buying beauty products which is a huge number. And the rest are the $17.2 \%$ respondents who choose other platforms over Nykaa. 
- $18.62 \%$ respondents are impulsive customers, $15.17 \%$ are discount customers, $13.10 \%$ are the loyal customers, $7.59 \%$ are the new customers and $5.52 \%$ are the potential customers. These sum up to that $60 \%$ of the customers who chose Nykaa as their platform. $22.76 \%$ of respondents who do not purchase beauty products online and the rest are the $17.24 \%$ who purchase beauty products online but do not choose Nykaa as their platform to purchase. These two sum up to the $40 \%$ of the respondents who fall under the option "did not opt."

- $19.31 \%$ of the respondents are highly reliable and $26.90 \%$ of them are reliable from the total of $60 \%$ of the respondents who choose Nykaa. $13.10 \%$ of the respondents are neutral about the reliability.

- $\quad 20.7 \%$ are strongly satisfied with the brand, $30.3 \%$ are satisfied and $9.0 \%$ are neutral about the satisfactory level.

- $13.8 \%$ of the respondents from the $60 \%$ of the respondents who chose Nykaa have responded "no" when asked if they would choose any other platform similar to Nykaa. 30.3\% have responded "maybe" which means they do not have a clarity about it. 15.9\% have responded that they would choose.

- Amongst the $22.76 \%$ of the respondents who do not purchase beauty products online, $10.3 \%$ of the respondents said that they never got the need to buy. $4.8 \%$ of the respondents said that they are not interested in beauty products and $7.6 \%$ of the respondents said that they prefer offline shopping over online as offline gives more personalized experience.

- The significant value of the reliability test is 0.867 which is greater than 0.7 , this signifies that the data is reliable.

- The significant value of the chi-square is 0.708 i.e. the value is greater than 0.05 . So we accept the null hypothesis, that age has no significant effect on consumer buying behaviour and we reject the alternate hypothesis, that the age has significant effect on consumer buying behaviour.

- It was found that significant values of availability of brands, price, social media/social media influencers and brand name are $0.007,0.045,0.001 \& 0.001$ respectively. These values are smaller than 0.05 . So we accept the alternate hypothesis for each of the following factors i.e. availability of brands, price, social media/social media influencers and brand name have a significant impact on the consumer buying behaviour. Therefore, we reject the null hypothesis for the same.

- It was also found that quality has significant value greater than 0.05 which is 0.195 , we accept the null hypothesis for the following i.e. quality has no significant effect on consumer buying behaviour and we reject the alternate hypothesis i.e. quality has a significant effect on consumer buying behaviour. 


\section{RECOMMENDATIONS}

- The company Nykaa can pitch its beauty products for men which apparently do not have a great reach amongst the consumers.

- As people are being more conscious about their skin, they are shifting to herbal products. Nykaa can promote its herbal products in order to increase its consumption which leads to increase in sales.

- The company can avail gift vouchers to its potential customers and new customers so that they can attract them to repeat their purchase.

\section{LIMITATIONS OF THE STUDY}

- The study is geographically restricted to Pune city only, and so the result cannot be extrapolated to other places. Also the result may differ from location to location.

- Sample size of the study was taken as 146 respondents taking time constraint as an important factor in mind.

- Findings of the study are based on the data collected from the sample respondents. There is a chance of false data due to lack of seriousness of the respondents while filling the survey.

- This study measures only the online buying behaviour of the consumers and does not measure the offline buying.

\section{CONCLUSION}

- As per the specified objectives and hypothesis, the study was accomplished successfully.It is concluded that the mentioned factors in the research have good influence on the consumer buying behaviour.

\section{REFERENCES}

Anjana, S.S., 2018. A study on factors influencing cosmetic buying behaviour of consumers. International Journal of Pure and Applied Mathematics, 118(9), pp.453-459.

Bhatt, S. and Bhatt, A., 2012. Factors influencing online shopping: an empirical study in Ahmedabad. The IUP Journal of Marketing Management, 9(4), pp.51-65.

Jadhav, V. and Khanna, M., 2016. Factors influencing online buying behavior of college students: A qualitative analysis. The Qualitative Report, 21(1), p.1.

Sharma, A., Bhola, S., Malyan, S. and Patni, N., 2013. Impact of brand loyalty on buying behavior of women consumers for beauty care products-Delhi region. Global Journal of Management and Business Studies, 3(7), pp.817-824.

Rastogi, A.K., 2010. A Study of Indian Online Consumers \& Their Buying Behaviour. International Research Journal, 1(10), pp.80-82. 
Prasad, A. and Gudimetla, S., 2019. A Study of Digital Shopping Behaviour of Women with Respect to Beauty and Personal Care Products. In Proceedings of 10th International Conference on Digital Strategies for Organizational Success.

Factors affecting consumer buying behavior

Article $\cdot$ September 2016

RamyaN, Dr S.A. MOHAMED Ali

WEBSITES:www.nykaa.com $\$$ www.economictimes.com

\section{APPENDIX-A}

\section{QUESTIONNAIRE}

1) Name:

2) Age group:

$\square \square 1520$
$\square \square 2925$
$\square \square 2530$
$\square \square 3040$
$\square \square 40$ \& above

3) Gender

$\square \square$ male

$\square \square$ female

4) Have you ever purchased beauty products online for yourself or to gift your loved ones?
$\square$ yes
$\square \square$ no

5) If yes, what are the online platforms that you choose to purchase your beauty products?

$\square \square$ Nykaa
$\square \square$ The Body Shop
$\square \square$ Purplle
$\square \square$ Lush
$\square \square$ others

6) If Nykaa, then rate the level of that these factors make on your purchase. 
SI $\quad \mathrm{I} \quad \mathrm{N} \quad \mathrm{NI} \quad \mathrm{SNI}$

The availability of brands

Affordability

Personalized customer service

Quality

Delivery system

Packaging

Discounts/gifts

Celebrity endorsements

Social media/its influencers

Brand name

[ SI - strongly influencing, I - influencing, N - neutral, NI - not influencing, SNI - strongly not influencing]

7) The above factors influence you to purchase from Nykaa. Rate the level of agreeableness to the statement.

Strongly agree

Stronglydisagree

8) What type of customer are you to Nykaa?

$\square \square$ potential customer

$\square \square$ new customer

$\square \square$ impulsive customer

$\square \square$ discount customer

$\square$ loyal customer

9) Rate the level of satisfaction with Nykaa.

Strongly dissatisfied $\square \square \quad \square \quad \square \quad \square \quad \square \quad \square$ Strongly satisfied

10) In case, there is any other beauty platform similar to Nykaa, would you change your platform from Nykaa?

$\square$ yes

$\square \square$ no

$\square \square$ maybe

SEPARATE SET OF QUESTIONS ASKED TO THOSE WHO SAID “NO" WHEN ASKED IF THEY HAVE PURCHASED BEAUTY PRODUCTS ONLINE. 
11) If no, what is the reason?

$\square \square$ neverhad the need to buy

$\square \square$ not interested in beauty products

$\square \square$ would rather go to the store and buy than shopping online

12) In case, you have to buy beauty products, let it be for any reason, which of the online platforms would you choose?
$\square \square$ Nykaa
$\square \square$ The Body Shop
$\square \square$ Purplle
$\square \square$ Lush
$\square \square$ Others

13) If Nykaa, as a first time buyer, what could be the factors that influence you to choose nykaa?

\section{Brand name}

Availability of brands

Affordability

Personalized customer service

Quality

Discounts/gifts

Celebrity endorsements

Social media/its influencers

14) Would you like to prefer Nykaa here after?
$\square \square$ yes
$\square \square$ no
$\square \square$ maybe

SI $\quad \mathrm{I} \quad \mathrm{N} \quad \mathrm{NI} \quad \mathrm{SNI}$

